\title{
Pomegranate as a Potential Alternative of Pain Management: A Review
}

\author{
José Antonio Guerrero-Solano ${ }^{1}$, Osmar Antonio Jaramillo-Morales ${ }^{1, * \mathbb{C} \text {, }}$ \\ Claudia Velázquez-González ${ }^{1}$, Minarda De la O-Arciniega ${ }^{1} \mathbb{D}$, Araceli Castañeda-Ovando ${ }^{2} \mathbb{D}$, \\ Gabriel Betanzos-Cabrera ${ }^{3}$ (D) and Mirandeli Bautista ${ }^{1, *}$ (D) \\ 1 Academic Area of Pharmacy, Institute of Health Sciences, Autonomous University of the State of Hidalgo, \\ Mexico, San Agustin Tlaxiaca, Hidalgo 42160, Mexico; jose_guerrero@uaeh.edu.mx (J.A.G.-S.); \\ claudiav@uaeh.edu.mx (C.V.-G.); mina@uaeh.edu.mx (M.D.1.O.-A.) \\ 2 Academic Area of Food Chemistry, Institute of Basic Sciences and Engineering, Autonomous University of \\ the State of Hidalgo, Mexico, Pachuca- Tulancingo km 4.5 Carboneras, Pachuca de Soto, \\ Hidalgo 42184, Mexico; ovandoa@uaeh.edu.mx \\ 3 Academic Area of Nutrition, Institute of Health Sciences, Autonomous University of the State of Hidalgo, \\ Mexico, San Agustin Tlaxiaca, Hidalgo 42160, Mexico; gbetanzo@uaeh.edu.mx \\ * Correspondence: osmar_jaramillo@uaeh.edu.mx (O.A.J.-M.); mibautista@uaeh.edu.mx (M.B.)
}

Received: 2 March 2020; Accepted: 27 March 2020; Published: 30 March 2020

\begin{abstract}
The use of complementary medicine has recently increased in an attempt to find effective alternative therapies that reduce the adverse effects of drugs. Punica granatum L. (pomegranate) has been used in traditional medicine for different kinds of pain. This review aims to explore the scientific evidence about the antinociceptive effect of pomegranate. A selection of original scientific articles that accomplished the inclusion criteria was carried out. It was found that different parts of pomegranate showed an antinociceptive effect; this effect can be due mainly by the presence of polyphenols, flavonoids, or fatty acids. It is suggested in the literature that the mechanisms of action may be related to the activation of the L-arginine / NO pathway, members of the TRP superfamily (TRPA1 or TRPV1) and the opioid system. The implications for the field are to know the mechanisms of action by which this effect is generated and thus be able to create alternative treatments for specific types of pain, which help alleviate it and reduce the adverse effects produced by drugs. The results propose that pomegranate and secondary metabolites could be considered in the treatment of inflammatory, nociceptive, and neuropathic pain.
\end{abstract}

Keywords: Pomegranate; Punica granatum L.; pain; antinociceptive

\section{Introduction}

Pomegranate (Punica granatum L.), the name derived from the Latin "pomus" and "granum," whose meaning is apple with grains, is the edible fruit of the pomegranate tree belonging to the Punicaceae family (this genus derives from the Phoenicians, who were active diffusers of their cultivation) [1]. The pomegranate tree is native to North Africa and the Middle East, although its cultivation has been worldwide, and some antecedents date back to ancient cultures (Babylonian, Greek, Hebrew, Persian, and Chinese) [2-4]. Besides the input to the human diet of pomegranate fruit, other parts of the tree, like leaves, roots, or flowers have been used in traditional medicine in many cultures because of its beneficial effects on health [5]. The most widespread use in the world of Punica granatum fruit is as an antimicrobial agent [6,7]. However, the juice, whole fruit, flowers, and roots have many other uses whose effects are reported in scientific reports: astringent, blisters, milkweed, cough [8], abortive [9], burns [10], hypoglycemic [11-13], dyslipidemia [14,15], antihypertensive [16,17], weight 
reduction [15,18], antiatherosclerotic [19,20], against erectile dysfunction [21] anti-inflammatory [22,23], metabolic syndrome [24,25], insulin resistance [26], anti-teratogenic [27-29], nephroprotective [30], antimicrobial, anti-fungic [23,31], wound healing [32], oral health [33] and pain, and effects that will be discussed in detail in this document. Thus, pain is defined by the International Association for the Study of Pain (IASP) as an unpleasant sensory and emotional experience associated with actual or potential tissue damage, or described in terms of such damage [34], the neural process of encoding noxious stimuli is called: nociception [35,36]. Woolf [37] classified pain according to its neurophysiological mechanism as 1) Nociceptive; a transient pain in response to a noxious stimulus, 2) Inflammatory; a spontaneous and hypersensitivity to pain in response to tissue damage and inflammation, 3) Neuropathic; a spontaneous pain and hypersensitivity to pain in association with damage or injury to the nervous system and 4) Functional; hypersensitivity to pain resulting from abnormal central processing. Despite the existence of a wide variety of therapeutic options used for the treatment of pain, this continues to be the main cause of medical consultation and is on the list of priority care diseases of the World Health Organization (WHO) [38]. Since 2009, the WHO reported that about $80 \%$ of the world's population did not have adequate access to pain relief [39]. Besides, according to the latest data found, 1.5 billion people in the world suffer from chronic pain, and it is estimated that the prevalence of chronic pain fluctuates between 11 and $40 \%$ of the population, of which up to $10 \%$ report that pain is severe [40,41]. Pain brings with them a series of comorbidities that end up completely affecting the quality of life, and becoming "per se" in a disabling disease. This review is focused on the effect of pomegranate on different nociception models, although the species was being used ancestrally for this purpose in traditional medicine. So the objective is to carry out a document of the existing scientific literature, the interventions performed, comparisons, results, and study designs in which the analgesic effect suggested by traditional medicine was verified (the review includes reports of studies of the pomegranate tree, including all its parts).

There are a wide variety of animal models used in the study of pain. Table 1 describes pain models used in pomegranate studies.

Table 1. Pain models used in pomegranate studies.

\begin{tabular}{|c|c|c|c|}
\hline Model of Pain & Type of Pain & Description & Reference \\
\hline Formalin test & $\begin{array}{l}\text { Nociceptive and } \\
\text { inflammatory }\end{array}$ & $\begin{array}{l}\text { Formalin (1-5\%) is injected into the dorsal surface of a } \\
\text { hind paw (ipsilateral) in rats or mice. The time the } \\
\text { animal spent licking, biting, or shaking is measured. } \\
\text { Two types of pain are measured at different test periods: } \\
\text { from } 0 \text { to } 15 \text { minutes (phase } 1 \text { - nociceptive pain), from } \\
15 \text { to } 60 \text { minutes (phase 2- inflammatory pain). }\end{array}$ & {$[36,42]$} \\
\hline Writhing test & $\begin{array}{l}\text { Inflammatory } \\
\text { (visceral pain) }\end{array}$ & $\begin{array}{l}\text { In the writhing test (mice), the antinociception is } \\
\text { evaluated by counting the number of writhes after a } \\
\text { parenteral administration of irritating agents (usually } \\
0.6 \% \text { acetic acid) during three periods of } 10 \mathrm{~min} . \mathrm{A} \\
\text { writhe is defined as the abdominal constriction and } \\
\text { stretching of at least one hind limb. }\end{array}$ & [43] \\
\hline Tail flick test & Nociceptive & $\begin{array}{l}\text { The tail-flick test (usually in rat) uses equipment in } \\
\text { which a small thermocouple contacts the dorsal surface } \\
\text { of the tail near the radiant heat stimulus. A computer } \\
\text { system is used to program the temperature and record } \\
\text { the latency of the tail in relation to the time taken to } \\
\text { move the limb. }\end{array}$ & [44] \\
\hline Hot- plate test & Nociceptive & $\begin{array}{l}\text { In the classical hot plate test, murines (usually rat) react } \\
\text { by licking their paws, jumping or both, and the number } \\
\text { of reactions in a period of time is measure } \\
\text { The latency time is measured from when the animal is } \\
\text { placed on the surface of the hot plate until the moment } \\
\text { the animal licks its leg or jumps to avoid thermal pain. }\end{array}$ & [44] \\
\hline
\end{tabular}


Table 1. Cont.

\begin{tabular}{|c|c|c|c|}
\hline Model of Pain & Type of Pain & Description & Reference \\
\hline Tail immersion test & Nociceptive & $\begin{array}{l}\text { In the tail immersion test (rat) baseline latency is the } \\
\text { time from immersion of the tail in warm water }\left(47^{\circ} \mathrm{C}\right) \\
\text { until the appearance of tail-flicking, vocalization or } \\
\text { struggling as a nociceptive response. }\end{array}$ & {$[45,46]$} \\
\hline Corneal pain & Nociceptive & $\begin{array}{l}\text { In this model, acute corneal nociception is induced ( } 1 \\
\text { hour after administering the drug to be studied), with a } \\
\text { drop of an irritant (usually } 5 \mathrm{M} \mathrm{NaCl} \text { ) on the surface of } \\
\text { the cornea of rats and the number of eye wipes is } \\
\text { measured during } 30 \mathrm{~s} \text {. }\end{array}$ & [47] \\
\hline Gastric ulcer & Inflammatory & $\begin{array}{l}\text { Gastric ulceration models are carried out with different } \\
\text { drugs in acute or chronic treatments (in rats). Usually } \\
\text { acetylsalicylic acid ( } 400 \mathrm{mg} / \mathrm{kg} \text { i.g.), indomethacin ( } 20 \\
-50 \mathrm{mg} / \mathrm{kg} \text { i.g.) and } 80 \% \text { ethanol. Subsequently, the ulcer } \\
\text { index (histopathology) is calculated. }\end{array}$ & {$[48-50]$} \\
\hline $\begin{array}{l}\text { Complete Freund's } \\
\text { adjuvant (CFA) }\end{array}$ & Inflammatory & $\begin{array}{l}\text { CFA (a solution of antigen emulsified in mineral oil and } \\
\text { inactivated dried mycobacteria) stimulates } \\
\text { cell-mediated immunity and leads to potentiation of } \mathrm{T} \\
\text { helper cells that produces effector T cells and } \\
\text { immunoglobulins. It is used exclusively in animal } \\
\text { research, due to its painful reaction and potential for } \\
\text { tissue damage. It is administered in the paw with a } \\
\text { subcutaneous injection of } 0.5 \mathrm{ml} \text { in rats. }\end{array}$ & {$[51]$} \\
\hline $\begin{array}{c}\text { Diabetic } \\
\text { neuropathy }\end{array}$ & Neuropathic & $\begin{array}{l}\text { It is reported that after six weeks of induction of } \\
\text { diabetes with alloxan }(180 \mathrm{mg} / \mathrm{kg} \text { i.p. }) \text { every } 48 \mathrm{~h} \text {, three } \\
\text { times, mice or rats generate diabetic neuropathy, } \\
\text { corroborated by tests of hyperalgesia and allodynia, } \\
\text { inducing a neuropathic pain model. }\end{array}$ & {$[52]$} \\
\hline $\begin{array}{c}\text { Tibial and sural } \\
\text { nerve transection }\end{array}$ & Neuropathic & $\begin{array}{l}\text { The rats are anesthetized, an incision is made in the } \\
\text { thigh, and a cut is made directly through the biceps } \\
\text { femoris muscle to expose the sciatic nerve and its three } \\
\text { terminal branches, two of which are ligated and cut } \\
\text { (tibial and sural). The muscle and skin close and over } \\
\text { time, hyperalgesia and allodynia are tested to } \\
\text { corroborate neuropathy. }\end{array}$ & {$[53,54]$} \\
\hline
\end{tabular}

\section{Results}

From a total of one hundred six articles, only 22 (21 preclinical and one clinical) meet the inclusion criteria. Table 2 (later in the document) was constructed from the analysis of data based on the part of the pomegranate studied, the pain model used, the species chosen for the study, the type of pomegranate sample (extracts, commercial products, juice, seeds, etc.) dose, route of administration, reference drug, and most relevant findings in each article. It was found that there is evidence of the antinociceptive effect by pomegranate, demonstrating, to some extent, that its use in traditional medicine has scientific support. Articles in which the effect of extracts of the whole fruit, the peel of the fruit, the juice and seeds (together), the leaves, and the flowers were used. Likewise, there are publications where the effect of ellagic acid is evaluated, which is a majority compound present in the pomegranate [55], and to which some authors attribute the antinociceptive effect [56-58], as well as some other polyphenols [59]. According to the data obtained, most of the extracts used are those of polar nature, with methanol and ethanol being the solvents mostly used. This may be because of the nature of the compounds that are likely responsible for the effect (polyphenols and flavonoids are polar). Therefore, we assume that the authors choose solvents because they are able to extract them in a better way. The doses used in the studies ranged from 10 to $3000 \mathrm{mg} / \mathrm{kg}$, the mode was $100 \mathrm{mg} / \mathrm{kg}$, followed by $200 \mathrm{mg} / \mathrm{kg}$, with a statistic mean of $123.8 \mathrm{mg} / \mathrm{kg}$. In general, the analysis of the Inhibition Pain Index (IPI), carried out that 100 $\mathrm{mg} / \mathrm{kg}$ of doses extract were effective, finding a dose-dependent antinociceptive response in all cases. The highest IPI was found at $3000 \mathrm{mg} / \mathrm{kg}$ weight in the writhing test. It should be noted that in most cases the effect of the extracts was comparable with that of their reference drug (without losing sight of 
the lower doses of the drugs). The most commonly used reference drug was morphine, and the extracts were close to matching the antinociceptive effect of nonsteroidal anti-inflammatory drugs (NSAIDs) at similar doses of the extracts. The parts of pomegranate with less antinociceptive activity were the leaves and flowers; however, more data are needed because only three studies were found. On the other hand, the part with the greatest antinociceptive effect is peel, a fact of great relevance since the peel is considered a waste product, and by having this effect, the product can be given a plus. In this sense, Quachrif et al. [60] studied the effect of the extract of two different varieties of pomegranate peel from Morocco (Amrouz and Sefri), the first variety was used just by herbalists and the second one is a variety of current consumption. The results showed that both varieties have a good antinociceptive effect, being Sefri the one with the greatest effect in the formalin test, Amrouz in writhing and tail immersion test, and in hot plate test, there were no differences. These models confirm the central and peripheral activity of the pomegranate peel; the Amrouz variety had a greater antinociceptive effect in most of the tests being more potent than Sefri. However, composition studies are recommended in which a hypothesis can be generated as to why this difference exists between varieties. This behavior can be related to the content of polyphenols and free organic acids of each variety. In Table 2, articles of the effect of ellagic acid on antinociception were included, since some of the articles suggest that this is the main responsibility for the antinociceptive effect of pomegranate. However, further in the text, we will see that this effect can be a synergy between several compounds present in the pomegranate, which also have been studied in isolation and reported as antinociceptives.

\section{Discussion}

After the whole revision, it must be said that the pomegranate tree and the different parts studied have antinociceptive activity in greater or lesser proportion on different types of pain (nociceptive, inflammatory, neuropathic, acute and chronic pain models). One of the objectives set for this review was to analyze the mechanisms of action of this effect. In this regard, the authors believe that the beneficial effects of pomegranate on pain are due to its phytochemical compounds. Pomegranate contains ellagitannins, gallotanins, flavonoids as anthocyanins, anthocyanidins and catechins, free organic acids (ellagic acid and gallic acid mainly), alkaloids, saponins, terpenoids, coumarins and fatty acids [55,61] among other groups of compounds. Although in most of the articles the authors agree that the phenolic compounds present in the pomegranate, are responsible for their analgesic and antinociceptive effects, the mechanisms of action have not been fully clarified, and few authors ventured to clarify them. In most cases, the authors attribute the antinociceptive effect of pomegranate to three groups of molecules: polyphenols (ellagitannins, free ellagic acid, tannins, gallotannins, and free gallic acid), flavonoids (anthocyanins), and fatty acids (punicic acid). In other cases, it is also assumed that the effect is given by the alkaloids.

\subsection{Mechanism of Action of the Principal Compounds of Pomegranate}

It has been reported that a pomegranate extract was able to inhibit the production of PGE2 and nitric oxide (NO) induced by inflammatory cytokines in vivo. These mechanisms could be mediated by the inhibition of the release of some endogenous nociceptive mediators and would confirm their central activity through supraspinal nociceptive activation [62]. Gainok et al., [63], suggested that antioxidants (flavonoids and polyphenols) optimize the biological actions of naturally occurring $\mathrm{NO}$ in vivo. In fact, antioxidants stabilize $\mathrm{NO}$ and prolong its cellular concentration, by protecting it against free radicals as a reactive oxygen species (ROS). NO, as a signaling molecule is synthesized from nitric oxide synthase (NOS) that catalyzes the reaction of molecular oxygen with the substrate amino acid L-arginine (L-Arg) to produce NO. NO acts as a modulator in the spinal cord and dorsal root ganglia through nociceptive pathways and mediates neuropathic pain [12-16]. 


\subsubsection{Tannins}

It has been reported that ellagitannins (polyphenols) are the most abundant bioactive compounds in pomegranate [64]. Pomegranate is a rich source of ellagitannins and ellagic acid derivatives such as punicalagin, punicalin, ellagic acid hexoside, and ellagic acid pentoside and corilagin [65] (Figure 1). Rosillo and Saad $[61,66]$ attribute the antinociceptive effects to tannins. They performed an in-vitro experiment where they exposed aortic endothelial cells to metabolites of ellagitannins (urolithin A glucuronide and its aglycones), which are a consequence of the action of the intestinal microbiota on ellagitannins, to determine the effect on monocyte adhesion and endothelial cell migration, which themselves were significantly inhibited with respect to controls. A decrease in the expression of the inflammatory chemokine CCL2 and Interleukin-8 (IL-8) was also observed [67]. Hollebeeck et al., [68] found that a pomegranate peel extract rich in punicalagin prevented chronic intestinal inflammation in Caco-2 cells. The experiment was performed in an in-vitro model of human intestinal epithelium, acting at the level of gene expression of the proinflammatory molecules interleukin- 6 and monocyte chemoattractant protein MCP-1) by direct molecular entrapment and a significant down-regulation of the transcription of these genes was observed. There are also reports of how four free hydrolyzable tannins (punicalagin, punicalin, strictin A and granatin B) showed an inhibitory effect on NO production in RAW 264.7 cells induced by lipopolysaccharide (LPS). Also, granatin B inhibited, to a greater extent, the production of PGE2 and the expression of COX-2 in the same cells. These tannins, especially granatin $\mathrm{B}$, function as an effective anti-inflammatory and have a double effect on anti-inflammation, by decreasing the production of PGE2 in the early stage, and the production of NO in the late stage. [59]. It has been reported that punicalagin- mediated inhibition of PGE2 production in macrophage cells stimulated with LPS was associated with negative regulation of COX-2 proteins [69]. In this regard, Jain et al. [53] observed that a commercial pomegranate fruit extract pretreatment significantly attenuated the increase NO level in a tibial and sural nerve transection induced neuropathic pain model. On the other hand, Karwasra et al. [70] investigated the effect of the pomegranate peel on the nociceptive threshold in acute and chronic cases of inflammation and pain in an animal model of rheumatoid arthritis. They found that $200 \mathrm{mg} / \mathrm{kg}$ of pomegranate peel extract showed a significant improvement $(\mathrm{p}<0.05)$ in nociceptive behavior reducing pain, the authors attributed this effect to the presence of high levels of hydrolyzed polyphenols, especially punicalagin, which may be responsible through modulation of NF- $\mathrm{kB}$ pathway. In the same way, Moreira et al. [71] showed that corilagin significantly reduced capsaicin-induced nociception, suggesting that this tannin may be involved in the antagonism of the transient receptor potential vanilloid 1 (TRPV1) channel, given that nociception evoked by capsaicin occurs by activation of the TRPV1 channel, which favors release of several chemical (substance P, aspartic and glutamic acids, neurokinin A, calcitonin gene-related peptide, NO) and pro-inflammatory mediators that contribute to increase nociception at central and peripheral levels [72,73].

\subsubsection{Flavonoids}

Flavonoids inhibit COX-2 activity, and it is known that nobiletin, flavone, resveratrol, quercetin penta-acetate, apigenin, chrysin, quercetin, galangin, and kaempferol (Figure 2), modulate COX-2 transcription in Caco2 cells, therefore, they play a role on analgesic activity and its mechanism is to target prostaglandins and inhibiting prostaglandin synthetase and tannins [74]. On the other hand, Takano-Ishikawa et al. [75] studied 39 flavonoids and their related compounds (comparison between subclasses), seeking a relationship between structure and activity of their inhibitory effects on the production of LPS-induced prostaglandin E2 in rat peritoneal macrophages. They found that flavones were the most effective, followed by flavanones and flavonols, which were the least effective. These results suggest that the double $\mathrm{C} 2-\mathrm{C} 3$ bond and the 4-oxo functional group of the $\mathrm{C}$ ring are responsible for the high inhibition activities. Likewise, flavonoids showed the greatest inhibitory effect on COX-2 gene expression. Finally, Gao et al. [76] found that Quercetin (20, $40 \mathrm{mg} / \mathrm{kg})$ for 40 and 12 days, respectively in a model of paclitaxel-induced neuropathic pain, suppressed the increased expression 
levels of TRPV1 in the spinal cords and dorsal root ganglion neurons (DRGs) of paclitaxel-treated rats and mice.
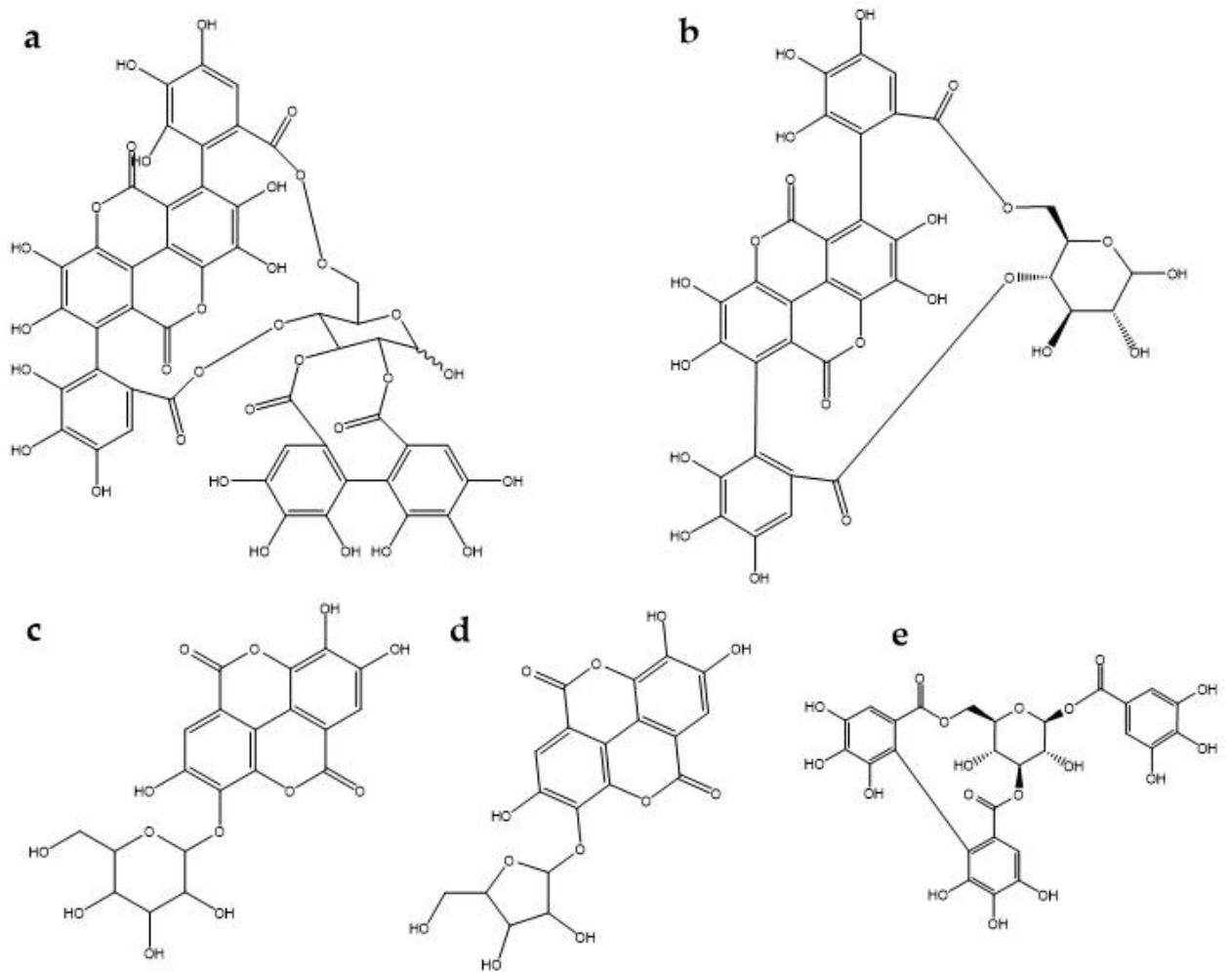

Figure 1. Chemical structure of some tannins involved in antinociception mechanisms. (a) punicalagin, (b) punicalin, (c) ellagic acid hexoside, (d) ellagic acid pentoside, (e) corilagin.<smiles>COc1ccc(-c2cc(=O)c3c(OC)c(OC)c(OC)c(OC)c3o2)cc1OC</smiles><smiles>O=c1cc(-c2ccccc2)oc2ccccc12</smiles><smiles>Oc1ccc(CCc2cc(O)cc(O)c2)cc1</smiles><smiles>CC(=O)Oc1cc(OC(C)=O)c2c(=O)c(OC(C)=O)c(-c3ccc(OC(C)=O)c(OC(C)=O)c3)oc2c1</smiles><smiles>COc1cc(-c2cc(=O)c3c(O)cc(O)cc3o2)cc(OC)c1O</smiles><smiles>O=c1c(O)c(-c2ccc(O)c(O)c2)oc2cc(O)cc(O)c12</smiles><smiles>O=c1c(O)c(-c2ccccc2)oc2cc(O)cc(O)c12</smiles><smiles>O=c1c(O)c(-c2ccc(O)cc2)oc2cc(O)cc(O)c12</smiles>

Figure 2. Chemical structure of some flavonoids that modulate COX-2 transcription. (a) nobiletin, (b) flavone, (c) resveratrol, (d) quercetin penta-acetate, (e) apigenin, (f) chrysin, (g) quercetin, (h) galangin, (i) kaempferol. 


\subsubsection{Ellagic Acid}

EA (Figure 3) is an organic acid, derived from gallic acid that occurs in free form, as EA-glycosides or as ellagitannins $[77,78]$. One hypotheses generated from the mechanism of action of the pomegranate (and its fractions) on nociception is that the EA is one of the responsible. Some studies confirm the antinociceptive activity of ellagic acid in animal models of visceral, inflammatory and cystitis pain. [57,79-82]. BenSaad et al. [56] suggest that ellagic acid and gallic acid present in the pomegranate extract they evaluated may be the compounds responsible for its analgesic effect. Ghorbanzadeh et al., in 2014, studied whether the L-arginine-NO / cGMP / KATP channel pathway is responsible for the antinociception of EA. It is known that the NO has pro or anti-nociceptive effects, depending on the conditions [83]. Kawabata et al. [58] showed that NO levels are increased in the formalin test by activating NOS at the injection site, which contributes to the induction of nociceptive responses in the second phase of the test. NO can increase the concentration of cGMP, which will lead to the activation of potassium channels. The opening of these channels induces membrane hyperpolarization and reduces depolarization and action potential. Therefore, Ghorbanzadeh et al., showed that prior treatment with L-arginine, N $\omega$-nitro-L-arginine methyl (L-NAME) (non-selective NOS inhibitor), sodium nitroprusside, methylene blue and glibenclamide, before the formalin test, were not effective in altering the antinociceptive effect of EA in the first phase of the test. Demonstrating that the antinociceptive effect of EA in this phase was not mediated by activation of the NO / cGMP / KATP channel pathway. On the other hand, it was shown that L-arginine and sodium nitroprusside potentiated the late-stage antinociceptive effect, and it was found that the effect of EA depends on the activation of the L-arginine / NO pathway. As there was a significant dose-dependent reduction in EA-induced peripheral antinociception after intraplantar administration of L-NAME in the late phase of the formalin test. When applied alone, L-NAME $(100 \mu \mathrm{g})$ did not produce any significant change. Therefore it has no hyperalgesia or anti-hyperalgesia effect, and the effect of EA is partly due to the local generation of NO. In other studies, it was shown that systemic administration of EA produced clear dose-dependent antinociceptive effects in both phases of the formalin test, finding that in the second phase, it was more sensitive to EA. Their results indicated that systemic analgesic effects and peripherals of EA depend on the opioid system, since prior treatment with naloxone, an opioid receptor antagonist, reversed the antinociception caused not only by i.p. EA, but also i.pl. [79-81,84]. Also, the analgesic action of EA has been explained by the inhibition of cyclooxygenase, which synthesizes prostaglandins at the sites of peripheral cell damage [85].<smiles>O=c1oc2c(O)c(O)cc3c(=O)oc4c(O)c(O)cc1c4c23</smiles><smiles>O=C(O)c1cc(O)c(O)c(O)c1</smiles><smiles>C/C=C\C=C/C/C=C\CCCCCCCC(=O)O</smiles>

Figure 3. Chemical structures involved in the antinociceptive effect of Punica granatum L. (a) ellagic acid, (b) gallic acid, (c) punicic acid. 


\subsubsection{Gallic Acid}

Gallic acid (GA) (Figure 3) is a trihydroxybenzoic acid in which the hydroxy groups are at positions 3, 4, and 5 [86]. BenSaad et al., [87], confirmed in 2017 that gallic acid reduced NO production in RAW2674.7 cells treated with LPS. Gallic acid was also shown to inhibit the production of PGE-2 and effectively decreased to IL-6 in this study. All these effects were dose-dependent. They also found that the expression of the COX-2 gene of RAW264.7 cells induced by LPS was not affected after treatment with gallic acid for $24 \mathrm{~h}$. In addition Santos et al., [88] observed an antihyperalgesic and antinociceptive effect by gallic acid in relation to the dose in nociception animal models. GA significantly inhibited substance $P$ and bradykinin-induced hyperalgesia in the rat leg but did not affect the hyperalgesia caused by prostaglandin $\mathrm{E}$ or carrageenan. In addition, GA, in contrast to the reference drug (morphine), was ineffective in the hot plate test in mice. The antinociception produced by GA i.p. in the formalin test was significantly reversed with G. pertussis toxin, i.c.v. and by intrathecal administration of $\mathrm{K}+$ channel blockers such as glibenclamide, apamine and caribotoxin, but not by tetraethylammonium. In contrast, GA antinociception was not affected by intraperitoneal treatment with naloxone or with nitric oxide precursor, L-arginine, and this action was not secondary to its anti-inflammatory effect, nor was it associated with nonspecific effects such as muscle relaxation. or sedation, as can be said, that GA produces a pronounced and dose-dependent systemic, spinal, and supraspinal antinociception in mice, perhaps by the activation of $\mathrm{K}+$ channels and by a mechanism sensitive to G. pertussis toxin. Finally, in another study, Trevisan et al., [89] considered identifying GA as an antagonist of transient receptor potential ankyrin 1 (TRPA1) channels, this channel play an integral role in pain and neurogenic inflammation via sensory nerve activation at both central and peripheral level $(\mathbf{7 2}, 73)$ and observing its antinociceptive effects in different pain models in Swiss mice. First, they evaluated the ability of GA to affect the calcium input induced by cinnamaldehyde; then they observed the antinociception by oral administration of GA (3-100 mg/ $/ \mathrm{kg}$ ) after intraplantar injection of TRPA1 agonists (allyl isothiocyanate, cinnamaldehyde or hydrogen peroxide) in an inflammatory pain model (carrageenan injection i.pl.), and a model of neuropathic pain (chronic constriction injury). GA reduced calcium entry mediated by activation of TRPA1, decreased nociception caused by allyl isothiocyanate, cinnamaldehyde, and hydrogen peroxide. Carrageenan-induced allodynia and edema were greatly reduced by GA treatment. Besides, the administration of GA was also able to decrease cold and mechanical allodynia in the neuropathic pain model. Therefore, GA was found to be a TRPA1 antagonist with antinociceptive properties.

\subsubsection{Punicic Acid}

Punicic / Punic acid (PUA), also called trichosanic acid (Figure 3), is an omega-5 long chain polyunsaturated fatty acid and an isomer of conjugated $\alpha$-linolenic acid with structural similarities to conjugated linoleic acid and $\alpha$-linolenic acid [90]. This fatty acid caused a dose-dependent increase in the peroxisome proliferator activator receptor (PPAR) alpha and gamma indicator activity in 3T3-L1 cells and bound, although weakly, to the ligand binding domain (LBD) of human gamma PPAR. Dietary PUA suppressed NF-kappa $\beta$ activation, TNF- $\alpha$ expression and PPAR $\alpha$ and $\gamma$ response genes regulated upward in skeletal muscle and adipose tissue. The loss of PPAR $\gamma$ affected the ability of diet PUA to improve glucose homeostasis and suppress inflammation in obese mice. Boussetta et al. [91] demonstrated that PUA exerts a potent anti-inflammatory effect through inhibition of TNF- $\alpha$-induced priming of NADPH oxidase by attacking p38MAPKinase / Ser345-p47phox-axis and releasing myeloperoxidase in a rat model of 2, 4, 6- trinitrobenzenesulfonic acid (TNBS) induced colitis.

\subsection{Toxicity}

It is relevant that once the mechanisms of action and the doses used in the different pain models have been studied, we know the toxicity of the studied parts of the plant. The consumption of the edible parts of the pomegranate and its extracts is considered safe. It has shown that a food grade 
pomegranate fruit extract, administered orally, in an acute toxicity study, had a $\mathrm{LD}_{50}$ of more than $5000 \mathrm{mg} / \mathrm{kg}$ in Wistar rats and Swiss albino mice and in the sub chronic study all animals survived and no changes in clinical parameters (physical and behavioral) were observed [92]. In other study, the result of the oral acute toxicity (OECD 2001), revealed no signs of toxicity in a peel extract at fixed sole dose of $2000 \mathrm{mg} / \mathrm{kg}$ for 14 days [93]. In addition, the butanolic fraction of methanolic extract of pomegranate peel was evaluated in an acute toxicity test, finding that it, was safe at a dose above $500 \mathrm{mg} / \mathrm{kg}$ [94]. However, some extracts from other parts may have toxic effects at high doses due to their high content of alkaloids and tannins. Part of the pomegranate tree can also influence the degree of toxicity, for example, it was found that $\mathrm{LD}_{50}$ of peel extract (intraperitoneally administration of two varieties from Morocco) is $320.5-355.8 \mathrm{mg} / \mathrm{kg}$ in Wistar rats and 300-348.2 mg/kg in albino mice respectively [60]. Vidal et al. [95], found that $\mathrm{LD}_{50}$ of hydro alcoholic whole fruit extract of pomegranate administered intraperitoneally to mice was $731.1 \mathrm{mg} / \mathrm{kg}$ and found that there are embryotoxicity at a dose greater than $100 \mathrm{mg} / \mathrm{kg}$. It has also been reported that punicalagins (an abundant tannin in pomegranate), has a cytotoxic effect on cell lines, at high concentrations [96]. However, Cerdá et al. [97], conducted a trial in which they concluded that oral administration of high doses (a commercial diet containing $0.5,2,5,10$ and $20 \%$ of peel extract) of punicalagin from pomegranate elagitannins to Wistar rats for 37 days is not toxic, and corroborated it with an histopathological study of liver and kidney.

\section{Materials and Methods}

\subsection{Search Criteria}

A search for information on the subject was carried out, using as inclusion criteria articles published from 2000 to September, 2019. Only peer reviewed articles published, with no language restrictions were considered in this study (unpublished data were not included). Articles which includes information of pomegranate and pain (nociception) were selected with the keywords: pomegranate, Punica granatum L., antinociceptive, analgesic, pain, anti-inflammatory, neuropathic, pomegranate seed, leaf, peel, aerial parts, juice, in repositories such as PubMed, ScienceDirect, Cochrane Library, Worldwide science, Springer link, Refseek, for investigate and review the literature.

\subsection{Data Extraction}

Data were collected, summarized, analyzed, compared, discussed, and the conclusions were made accordingly. Data extracted from each study included pain model, type of pain, part of pomegranate studied, species studied, and type of extract or compound, dose and route of administration, reference drug, results and an analyses of the mechanisms of action. Studies in which the objective was the exclusive evaluation of the anti-inflammatory effect were not taken into account. The reviewers extracted the data through an analysis of the interventions, the results of their viability were also compared, taking into account the study designs of the articles.

Table 2. Effect of different parts of pomegranate on nociception and analgesia in many pain models.

\begin{tabular}{|c|c|c|c|c|c|c|c|}
\hline $\begin{array}{c}\text { Part of the } \\
\text { Pomegranate } \\
\text { Tree }\end{array}$ & Pain Model & Species & Sample & $\begin{array}{c}\text { Doses and Route } \\
\text { of Administration } \\
(\mathrm{mg} / \mathrm{kg})\end{array}$ & $\begin{array}{l}\text { Reference } \\
\text { Drug } \\
(\mathrm{mg} / \mathrm{kg})\end{array}$ & $\begin{array}{c}\text { Results }(p<0.05) \text { and } \\
\text { IPI }(\%)\end{array}$ & Ref. \\
\hline \multirow[t]{3}{*}{ Whole fruit } & Formalin test & $\begin{array}{l}\text { Adult male Swiss } \\
\text { albino mice }\end{array}$ & $\begin{array}{l}\text { Commercial } \\
\text { extract (high } \\
\text { ellagitannins } \\
\text { content) }\end{array}$ & 10, 30, 100 i.p. & $\begin{array}{l}\text { Diclofenac } \\
100 \text { i.p. }\end{array}$ & $\begin{array}{l}\text { The } 100 \mathrm{mg} \text { dose reduced } \\
\text { nociception in both phases of } \\
\text { the formalin test } \\
\text { IPI: Not reported }\end{array}$ & [98] \\
\hline & $\begin{array}{l}\text { Writhing test } \\
\text { Hot-tail flick test } \\
\text { Plantar test }\end{array}$ & $\begin{array}{c}\text { Adult male } \\
\text { albino mice } \\
\text { Adult male } \\
\text { Sprague Dawley } \\
\text { rat }\end{array}$ & Ethanolic Extract & $100,150,200$ i.p. & $\begin{array}{l}\text { Acetylsalicylic } \\
\text { acid (ASA) } \\
100 \text { i.p. }\end{array}$ & $\begin{array}{c}\text { Reduce writhes, flicks and } \\
\text { hyperalgesia in plantar test } \\
\text { IPI: } \\
\text { Writhing: } 37 \text { (59 ASA) } \\
\text { Hot tail flick: } 24 \text { (37.5 ASA) }\end{array}$ & [99] \\
\hline & $\begin{array}{l}\text { Writhing test } \\
\text { Hot tail-flick test } \\
\text { Plantar test }\end{array}$ & $\begin{array}{c}\text { Adult male } \\
\text { albino mice } \\
\text { Adult male } \\
\text { Sprague Dawley } \\
\text { rat }\end{array}$ & $\begin{array}{l}\text { Ethyl acetate } \\
\text { extract }\end{array}$ & $100,150,200$ i.p. & ASA 100 i.p. & $\begin{array}{c}\text { Reduce writhes, flicks and } \\
\text { hyperalgesia in plantar test } \\
\text { IPI: } \\
\text { Writhing: } 41 \text { (53 ASA) } \\
\text { Hot tail flick: } 30.5 \text { (43.8 ASA) }\end{array}$ & [56] \\
\hline
\end{tabular}


Table 2. Cont

\begin{tabular}{|c|c|c|c|c|c|c|c|}
\hline $\begin{array}{c}\text { Part of the } \\
\text { Pomegranate } \\
\text { Tree }\end{array}$ & Pain Model & Species & Sample & $\begin{array}{c}\text { Doses and Route } \\
\text { of Administration } \\
(\mathrm{mg} / \mathrm{kg})\end{array}$ & $\begin{array}{l}\text { Reference } \\
\text { Drug } \\
(\mathrm{mg} / \mathrm{kg})\end{array}$ & $\begin{array}{c}\text { Results }(p<0.05) \text { and } \\
\text { IPI }(\%)\end{array}$ & Ref. \\
\hline & $\begin{array}{c}\text { Writhing test } \\
\text { Hot-plate test } \\
\text { Tail immersion } \\
\text { test }\end{array}$ & $\begin{array}{l}\text { Adult male } \\
\text { albino mice }\end{array}$ & $\begin{array}{l}\text { Hydro-alcoholic } \\
\text { extract }\end{array}$ & $\begin{array}{l}1000,2000 \text { and } \\
3000 \text { per os. }\end{array}$ & $\begin{array}{c}\text { ASA: } 100 \text { per } \\
\text { os }\end{array}$ & $\begin{array}{l}\text { Reduce writhes } \\
\text { Increased time of reaction } \\
\text { latency in the tail immersion } \\
\text { test in response to thermal } \\
\text { stimulation } \\
\text { IPI: Writhing: } 1 \mathrm{~g}=45.3 \text {, } \\
2 \mathrm{~g}=70.9,3 \mathrm{~g}=86.8\end{array}$ & [62] \\
\hline & $\begin{array}{l}\text { Tibial and sural } \\
\text { nerve } \\
\text { transection }\end{array}$ & $\begin{array}{l}\text { Adult Wistar rats } \\
\text { of either sex }\end{array}$ & $\begin{array}{c}\text { Commercial Fruit } \\
\text { Extract }\end{array}$ & $\begin{array}{l}100,300 \\
\text { per os }\end{array}$ & $\begin{array}{l}\text { Gabapentin } \\
100 \text { per os }\end{array}$ & $\begin{array}{l}\text { At both doses significantly } \\
\text { attenuated the biochemical } \\
\text { changes (TNF- } \alpha, \text { TBARS, } \\
\text { GSH and Nitrite) and } \\
\text { behavior (hyperalgesia and } \\
\text { allodynia) induced by nerve } \\
\text { surgery. Also attenuated the } \\
\text { tibial functional index. } \\
\text { IPI: No data }\end{array}$ & [53] \\
\hline \multirow[t]{8}{*}{ Fruit peel } & Osteoarthritis & Adult women & $\begin{array}{l}\text { Hydro-alcoholic } \\
\text { extract }\end{array}$ & $\begin{array}{c}500 \text { each } 12 \text { hours } \\
\text { during } 8 \text { weeks per } \\
\text { os }\end{array}$ & No data & $\begin{array}{l}\text { A decrease in the KOOS } \\
\text { (instrumental evaluation of } \\
\text { knee injury and score of the } \\
\text { result of osteoarthritis), and a } \\
\text { decrease in the visual analog } \\
\text { scale } \\
\text { IPI: No data }\end{array}$ & [100] \\
\hline & $\begin{array}{l}\text { Hot-plate } \\
\text { CFA }\end{array}$ & $\begin{array}{l}\text { Adult Wistar rats } \\
\text { (sex not } \\
\text { specified) }\end{array}$ & $\begin{array}{l}\text { Lyophilized } \\
\text { powder of } \\
\text { hydro-alcoholic } \\
\text { standardized } \\
\text { peel extract }\end{array}$ & $50,100,200$ per os & $\begin{array}{l}\text { Indomethacin: } \\
3 \text { per os }\end{array}$ & $\begin{array}{c}\text { The resistance to thermal } \\
\text { nociception was greater at } \\
\text { doses of } 200 \mathrm{mg} / \mathrm{kg}(p<0.05) \text {, } \\
\text { finding an effect comparable } \\
\text { to the reference drug. } \\
\text { IPI: } 58-75 \% \\
\text { In CFA test, treatment } \\
\text { suppressed inflammation of } \\
\text { the hind leg and bone } \\
\text { damage, and at } 200 \mathrm{mg} / \mathrm{kg} \text {, } \\
\text { against changes related to } \\
\text { CFA }\end{array}$ & [70] \\
\hline & Hot-tail flick test & Male Wistar rats & $\begin{array}{l}\text { Hydro-alcoholic } \\
\text { extract }\end{array}$ & 100,200 per os & $\begin{array}{l}\text { Indomethacin } \\
20 \text { per os }\end{array}$ & $\begin{array}{l}100 \text { and } 200 \mathrm{mg} / \mathrm{kg} \text { of } \\
\text { hydroalcoholic extract } \\
\text { produced analgesic activity } \\
\text { comparable to the reference } \\
\text { drug. } \\
\text { IPI: No data }\end{array}$ & [50] \\
\hline & $\begin{array}{c}\text { Writhing test } \\
\text { Formalin test } \\
\text { Hot-plate test } \\
\text { Tail immersion } \\
\text { test }\end{array}$ & $\begin{array}{c}\text { Adult male } \\
\text { Wistar rats } \\
\text { Adult albino } \\
\text { mice }\end{array}$ & $\begin{array}{l}\text { Methanolic } \\
\text { extract }\end{array}$ & $\begin{array}{c}10,25,50,100,150 \\
\text { i.p. and i.c.v }\end{array}$ & $\begin{array}{l}\text { Morphine } \\
\text { sulfate: } 5 \text { i.p } \\
\text { and i.c.v. } \\
\text { DL-lysine } \\
\text { acetylsalicylates: } \\
\quad 100 \\
\text { i.p. and i.c.v }\end{array}$ & $\begin{array}{l}\text { Produced an antinociceptive } \\
\text { effect in all tests. In the } \\
\text { hot-plate and immersion test, } \\
\text { increase dose- dependent } \\
\text { reaction latency to thermal } \\
\text { stimuli } \\
\text { IPI: } \\
\text { Formalin: } 75-82 \\
\text { Writhing: } 29-52\end{array}$ & [60] \\
\hline & $\begin{array}{l}\text { Formalin test } \\
\text { Writhing test }\end{array}$ & $\begin{array}{l}\text { Adult male } \\
\text { Albino mice }\end{array}$ & $\begin{array}{l}\text { Hydroalcoholic } \\
\text { extract }\end{array}$ & 400 i.p. & No data & $\begin{array}{l}\text { Pomegranate peel extract has } \\
\text { analgesic and } \\
\text { anti-inflammatory effect in } \\
\text { formalin and acetic acid } \\
\text { models. } \\
\text { IPI: Not reported }\end{array}$ & [101] \\
\hline & $\begin{array}{l}\text { CFA-induced } \\
\text { polyarthritis } \\
\text { von Frey test } \\
\text { Formalin test }\end{array}$ & $\begin{array}{c}\text { Adult male } \\
\text { Wistar rats } \\
\text { Adult male ICR } \\
\text { mice }\end{array}$ & $\begin{array}{l}\text { Methanolic } \\
\text { extract } \\
\text { Ellagic acid as } \\
\text { marker } \\
\text { compound }\end{array}$ & $\begin{array}{l}300 \text { for CFA100 for } \\
\text { formalin test } \\
\text { Topic formulation }\end{array}$ & $\begin{array}{c}1 \% \text { diclofenac } \\
\text { gel }\end{array}$ & $\begin{array}{c}\text { In CFA and mechanical } \\
\text { hyperalgesia test it was } \\
\text { found that ellagic acid was } \\
\text { only effective at } 0.65 \text { and } \\
0.32 \% \text {, and both (EA and } \\
\text { pomegranate peel extract } \\
\text { showed significant topical } \\
\text { analgesic activities). } \\
\text { IPI: } \\
\text { Formalin test phase } 1 \text { was not } \\
\text { inhibit. } \\
\text { Formalin test phase } 2: 35.63 \\
\text { for extract and } 33.76 \text { for EA }\end{array}$ & [102] \\
\hline & $\begin{array}{l}\text { Painful diabetic } \\
\text { neuropathy } \\
\text { Hot-plate } \\
\text { Tail flick }\end{array}$ & $\begin{array}{c}\text { Alloxan-induced } \\
\text { DM adult male } \\
\text { Swiss-Webster } \\
\text { mice }\end{array}$ & $\begin{array}{l}\text { Spray-dried } \\
\text { biopolymeric } \\
\text { dispersions from } \\
\text { ethanolic extract } \\
\text { (commercial) } \\
\text { Gallic acid }\end{array}$ & 25,50 and 100 i.p. & $\begin{array}{l}\text { Tramadol: } 10 \\
\text { per os } \\
\text { Glibenclamide: } \\
5 \text { per os }\end{array}$ & $\begin{array}{l}\text { The extract improved } \\
\text { peripheral nerve function in } \\
\text { all latency tests, in hot-plate } \\
\text { latency compared to control } \\
\text { group by } 33.3,73.5 \text {, and } \\
85.1 \% \text { in doses of } 25,50 \text {, and } \\
100 \mathrm{mg} / \mathrm{kg} \text {, respectively. }\end{array}$ & [52] \\
\hline & $\begin{array}{l}\text { Ethanol ( } 80 \%) \\
\text { and ASA } \\
\text { induction of } \\
\text { gastric ulcer }\end{array}$ & $\begin{array}{l}\text { Adult male } \\
\text { Wistar rats }\end{array}$ & $\begin{array}{l}\text { Methanolic } \\
\text { extract }\end{array}$ & 250 and 500 & No data & $\begin{array}{c}\text { The extract has a } \\
\text { gastroprotective effect } \\
\text { IPI: } \\
22.37 \text { and } 74.21 \% \text { Ethanol } \\
\text { ulcer } \\
21.95 \text { and } 63.41 \% \text { ASA ulcer }\end{array}$ & [48] \\
\hline
\end{tabular}


Table 2. Cont

\begin{tabular}{|c|c|c|c|c|c|c|c|}
\hline $\begin{array}{c}\text { Part of the } \\
\text { Pomegranate } \\
\text { Tree }\end{array}$ & Pain Model & Species & Sample & $\begin{array}{c}\text { Doses and Route } \\
\text { of Administration } \\
(\mathrm{mg} / \mathrm{kg})\end{array}$ & $\begin{array}{l}\text { Reference } \\
\text { Drug } \\
(\mathrm{mg} / \mathrm{kg})\end{array}$ & $\begin{array}{c}\text { Results }(p<0.05) \text { and } \\
\text { IPI }(\%)\end{array}$ & Ref. \\
\hline \multirow[t]{3}{*}{$\begin{array}{l}\text { Juice and } \\
\text { seed }\end{array}$} & $\begin{array}{l}\text { Hot- tail flick } \\
\text { test } \\
\text { Hot- plate test }\end{array}$ & $\begin{array}{l}\text { Old and young } \\
\text { male Swiss mice }\end{array}$ & $\begin{array}{l}\text { Ethanolic seed } \\
\text { extract }\end{array}$ & $100,250,500$ per os & $\begin{array}{l}\text { Morphine } \\
\text { sulfate } \\
5 \text { per os }\end{array}$ & $\begin{array}{l}\text { The seed extract revealed an } \\
\text { antinociceptive property } \\
\text { (being similar to the reference } \\
\text { drug) at doses of } 250 \text { and } 500 \\
\mathrm{mg} / \mathrm{kg} \text {. There were no } \\
\text { differences due to age of the } \\
\text { mice. }\end{array}$ & [103] \\
\hline & $\begin{array}{l}\text { Writhing test } \\
\text { CFA }\end{array}$ & $\begin{array}{l}\text { Adult male Swiss } \\
\text { albino mice }\end{array}$ & $\begin{array}{l}\text { Seed oil + } \\
\text { ketoprofen } \\
\text { nanoemulsion }\end{array}$ & $\begin{array}{l}300+10 \text { i.g. } \\
\text { Doses response } \\
\text { curve: } 30-150+ \\
0.1-5 \text { i.g. }\end{array}$ & No data & $\begin{array}{l}\text { The nanoemulsion reduced } \\
\text { writhes with an effect of } 12 \\
\text { hours maximum compared to } \\
\text { ketoprofen ( } 3 \text { hours). Also an } \\
\text { effect was found in the dose- } \\
\text { response curve at a dose of } 1 \\
\mathrm{mg} / \mathrm{kg} \text { for the nanoemulsion } \\
\text { and } 0.5 \mathrm{mg} / \mathrm{kg} \text { for ketoprofen. } \\
\text { The evaluation of mechanical } \\
\text { allodynia in the CFA test } \\
\text { showed that nanoemulsions } \\
\text { had an effect up to } 10 \text { hours, } \\
\text { compared to ketoprofen ( } 6 \\
\text { hours) } \\
\text { IPI: Not reported }\end{array}$ & [104] \\
\hline & $\begin{array}{c}\text { Hypertonic } \\
\text { saline- induced } \\
\text { corneal pain }\end{array}$ & $\begin{array}{l}\text { Adult male mice } \\
\text { (unspecified } \\
\text { strain) }\end{array}$ & $\begin{array}{l}\text { Juice and seed } \\
\text { extracts }\end{array}$ & $\begin{array}{c}2,4,6 \mathrm{~mL} / \mathrm{kg} \text { acute } \\
\text { doses per os } \\
1,2,3 \mathrm{~mL} / \mathrm{kg} \\
\text { chronic } \text { per os }\end{array}$ & $\begin{array}{l}\text { Morphine: } 2 \\
\text { s.c. } \\
\text { Naloxone: } 2 \\
\text { s.c. }\end{array}$ & $\begin{array}{l}\text { The results showed that the } \\
\text { high acute dose, and the } \\
\text { lower dose in the chronic test, } \\
\text { can decrease acute corneal } \\
\text { pain and enhance morphine } \\
\text { induced nociception }\end{array}$ & [105] \\
\hline \multirow[t]{3}{*}{$\begin{array}{l}\text { Leaves and } \\
\text { flower }\end{array}$} & Hot-plate test & $\begin{array}{l}\text { Adult male Swiss } \\
\text { albino mice }\end{array}$ & $\begin{array}{c}\text { Chloroformic, } \\
\text { methanolic and } \\
\text { aqueous extract } \\
\text { of flower }\end{array}$ & 50 i.p. & $\begin{array}{l}\text { Morphine } \\
\text { sulfate } \\
5 \text { i.p. }\end{array}$ & $\begin{array}{l}\text { The reaction time after the } \\
\text { injection was longer than the } \\
\text { control group, and similar to } \\
\text { the effect of morphine. The } \\
\text { time at which the maximum } \\
\text { analgesia was observed for } \\
\text { the three extracts was } 60 \\
\text { minutes } \\
\text { IPI: Not reported }\end{array}$ & [106] \\
\hline & Writhing test & $\begin{array}{c}\text { Adult male Swiss } \\
\text { albino mice } \\
\text { Adult male Long } \\
\text { Evans rats }\end{array}$ & $\begin{array}{l}\text { Per-ether, } \\
\text { dichloromethane } \\
\text { and methanol }\end{array}$ & 200 per os & $\begin{array}{l}\text { Diclofenac: } \\
50 \text { per os }\end{array}$ & $\begin{array}{l}\text { Extracts and diclofenac have } \\
\text { induced significant decrease } \\
\text { in the number of writhes } \\
\text { when compared to the } \\
\text { control groups. } \\
\text { IPI } \\
\text { Diclofenac } 61.8 \text {, Pet-ether } \\
\text { 75.7, dichloromethane } 68.5 \text {, } \\
\text { methanol } 54.7\end{array}$ & [107] \\
\hline & Writhing test & $\begin{array}{l}\text { Either sex adult } \\
\text { Swiss albino mice }\end{array}$ & $\begin{array}{l}\text { Hydro alcoholic } \\
\text { extract of leaf } \\
\text { and peel }\end{array}$ & 100 and 200 per os & $\begin{array}{l}\text { Ibuprofen } 100 \\
\text { per os }\end{array}$ & $\begin{array}{l}\text { The leaf and the peel at both } \\
\text { doses decreased the number } \\
\text { of contractions compared to } \\
\text { the control group, the leaf } \\
\text { having a lower IPI than peel } \\
\text { at both doses. } \\
\text { IPI: } \\
\text { Leaf: } 27.8 \text { and } 43.2 \\
\text { Peel: } 30.1 \text { and } 49.8\end{array}$ & [108] \\
\hline \multirow[t]{3}{*}{$\begin{array}{l}\text { Ellagic acid } \\
\text { as possible } \\
\text { responsible } \\
\text { for the effect }\end{array}$} & Formalin test & $\begin{array}{l}\text { Adult male } \\
\text { Wistar rats }\end{array}$ & Ellagic acid & $\begin{array}{c}0.03,0.06,0.10 .2 \\
\text { i.p. } \\
\text { i.pl. }\end{array}$ & $\begin{array}{c}\text { Morphine: } 25 \\
\mu \mathrm{g} / \text { paw }\end{array}$ & $\begin{array}{l}\text { EA induced local and } \\
\text { peripheral antinociception in } \\
\text { both phases of the formalin } \\
\text { test }(\text { doses of } 100 \text { and } \\
300 \mu \mathrm{g} / \mathrm{Kg})\end{array}$ & [57] \\
\hline & Formalin test & $\begin{array}{l}\text { Adult male } \\
\text { Wistar rats }\end{array}$ & Ellagic acid & $\begin{array}{l}\text { 1, 3, } 10,30 \\
\quad \text { i.pl }\end{array}$ & $\begin{array}{c}\text { Morphine } 5 \\
\text { i.p. } \\
\text { Indometacin } \\
10 \text { i.p. }\end{array}$ & $\begin{array}{l}\text { The ipsilateral administration } \\
\text { of EA into the right paw } \\
\text { produced a dose- related } \\
\text { antinociception local } \\
\text { peripheral during both } \\
\text { phases of the test } \\
\text { (comparable with morphine) } \\
\text { IPI: not reported }\end{array}$ & [80] \\
\hline & $\begin{array}{l}\text { Writhing test } \\
\text { Hot-plate test }\end{array}$ & $\begin{array}{l}\text { Adult male Swiss } \\
\text { albino mice }\end{array}$ & $\begin{array}{c}\text { Ellagic acid + } \\
\text { morphine }\end{array}$ & $\begin{array}{c}\text { Writhing: } \\
\text { EA 1-30 i.p. } \\
\text { Morphine } 0.25-3 \\
\text { i.p. } \\
\text { Hot-plate: } \\
\text { morphine } 10 \text { s.c. + } \\
\text { EA 1-10 i.p. }\end{array}$ & No data & $\begin{array}{l}\text { EA (1-30 mg/kg) showed } \\
\text { significant and dose- } \\
\text { dependent antinociceptive } \\
\text { effects in the writhing test, } \\
\text { interacted with morphine in } \\
\text { analgesia in a synergistic } \\
\text { manner and also exerted an } \\
\text { algic activity on the hot- plate } \\
\text { test (with morphine } \\
\text { effectively blocked the } \\
\text { development of tolerance to } \\
\text { morphine analgesia). } \\
\text { IPI: Not reported }\end{array}$ & [79] \\
\hline
\end{tabular}


Table 2. Cont.

\begin{tabular}{|c|c|c|c|c|c|c|c|}
\hline $\begin{array}{c}\text { Part of the } \\
\text { Pomegranate } \\
\text { Tree }\end{array}$ & Pain Model & Species & Sample & $\begin{array}{c}\text { Doses and Route } \\
\text { of Administration } \\
\text { (mg/kg) }\end{array}$ & $\begin{array}{c}\text { Reference } \\
\text { Drug } \\
(\mathrm{mg} / \mathrm{kg})\end{array}$ & $\begin{array}{c}\text { Results }(p<0.05) \text { and } \\
\text { IPI (\%) }\end{array}$ & Ref. \\
\hline & Writhing & $\begin{array}{l}\text { Adult male Swiss } \\
\text { albino mice }\end{array}$ & $\begin{array}{l}\text { Ellagic acid + } \\
\text { Venlafaxine } \\
\quad(\text { VLF) }\end{array}$ & $\begin{array}{l}\text { EA } 0.3,1,3,10 \text { i.p. } \\
\text { VLF } 3,10,30,60 \text { i.p. }\end{array}$ & No data & $\begin{array}{l}\text { A dose- dependent inhibition } \\
\text { of the contortion response } \\
\text { was achieved. The effective } \\
\text { dose } 50\left(\mathrm{ED}_{50}\right) \text { versus } \\
\text { contortion behaviors were } \\
1.02(0.86-1.19) \mathrm{mg} / \mathrm{Kg} \text {, and } \\
12.37(9.74-15.37) \mathrm{mg} / \mathrm{Kg} \text { for } \\
\text { EA and VLF respectively, } \\
\text { also with higher power than } \\
\text { VLF, so the combination of } \\
\text { EA and VLF has a synergistic } \\
\text { interaction. }\end{array}$ & [81] \\
\hline
\end{tabular}

Abbreviations: $\mathrm{CFA}=$ Complete Freund's adjuvant, i.p. $=$ intra peritoneal, i.g. $=$ intra gastric, i.c.v. $=$ intracerebroventricular, i.pl. = intraplantar, per os= oral route, s.c.= subcutaneous.

\section{Conclusions}

Through the reviewed articles, it has been proven that pomegranate and its different parts have an antinociceptive effect, through several preclinical pain models and a clinical model, paying particular attention to the effect of the fruit peel. It was described with certainty that certain compounds are responsible for the antinociceptive effect; however, the extracts have hundreds and even thousands of compounds, so there are still a large number of compounds that can be isolated and evaluated (not only polyphenols, flavonoids or fatty acids). The results are conclusive, given the certainty that pomegranate can be considered in the treatment of pain and could have a positive impact on the lives of people with acute and chronic pain. Pomegranate can be used primarily in inflammatory and nociceptive pain, but also neuropathic.

\section{Prospects}

More information is needed about the synergic effect of pomegranate or its compounds identified with drugs in order to test whether there is synergism, additivity, or antagonism of the extracts or compounds of pomegranate and to enhance the effectiveness of existing drugs, with the least number of undesirable effects, by reducing the effective doses thereof. It is also considered necessary that we have the development of more clinical studies where it the effect is proven (if these studies are to be tested in humans, regardless of toxicity reports, not only the bioactivity of the evaluated extracts should be sought, but also the chemistry of the extracts and the biological effect they may have in addition to the antinociception). It is also suggested that we with different extraction methods and solvents (for example, using non polar solvents) for those groups of compounds present in the various parts of the pomegranate and that have not been studied, such as alkaloids, saponins, and terpenoids, this because the antinociceptive effect possessed by the compounds identified in this article, could being enhanced by the presence of other groups of compounds and without knowing it, the effect is attributed only to antioxidant compounds. Finally, it is proposed that we evaluate more mechanisms of action with antagonists that have not been used by the authors cited in this review.

Author Contributions: Writing — original draft preparation \& Methodology, J.A.G.-S.; Formal analysis \& Supervision, C.V.-G., M.D.1.O.-A. and A.C.-O.; Investigation, G.B.-C.; Conceptualization, O.A.J.-M.; Conceptualization, writing-Review \& Editing, M.B. All authors have read and agreed to the published version of the manuscript.

Funding: One of the authors (J.A.G.S.) is grateful for a scholarship N.554424 provided by the National Council of Science and Technology of Mexico (CONACyT).

Conflicts of Interest: The authors declare that there are no conflict of interest in the publication of this article. 


\section{References}

1. Botti, C.; Prat, L.; Carrasco, O.; Loannidis, D.; Franck, N.; Osses, D. El Granado (Punica granatum L.); Agronómicas, S.C., Ed.; Facultad de Ciencias Agronómicas U de Chile: Santiago, Chile, 2002; pp. 50-56.

2. Labbe, M.; Ulloa, P.A.; Lopez, F.; Saenz, C.; Pena, A.; Salazar, F.N. Characterization of chemical compositions and bioactive compounds in juices from pomegranates ('Wonderful', 'Chaca' and 'Codpa') at different maturity stages. Chil. J. Agric. Res. 2016, 76, 479-486. [CrossRef]

3. Mertens-Talcott, S.U.; Jilma-Stohlawetz, P.; Rios, J.; Hingorani, L.; Derendorf, H. Absorption, metabolism, and antioxidant effects of pomegranate (Punica granatum L.) polyphenols after ingestion of a standardized extract in healthy human volunteers. J. Agric. Food Chem. 2006, 54, 8956-8961. [CrossRef] [PubMed]

4. Muthmann, F. Der Granatapfel: Symbol des Lebens in der Alten Welt; Office du Livre: Bern, Switzerland, 1982.

5. Karimi, M.; Sadeghi, R.; Kokini, J. Pomegranate as a promising opportunity in medicine and nanotechnology. Trends Food Sci. Technol. 2017, 69, 59-73. [CrossRef]

6. Kapoor, L. CRC Handbook of Ayurvedic Medicinal Plants, 1st ed.; CRC Press: New York, NY, USA, 2017.

7. Tanveer, A.; Farooq, U.; Akram, K.; Hayat, Z.; Shafi, A.; Nazar, H. Pomegranate extracts: A natural preventive measure against spoilage and pathogenic microorganisms. Food Rev. Int. 2015, 31, 29-51. [CrossRef]

8. Cáceres, A.; Girón, L.M.; Alvarado, S.R.; Torres, M.F. Screening of antimicrobial activity of plants popularly used in Guatemala for the treatment of dermatomucosal diseases. J. Ethnopharmacol. 1987, 20, $223-237$. [CrossRef]

9. King, H. Eve's herbs: A history of contraception and abortion in the West. Med. Hist. 1998, 42, 412-413. [CrossRef]

10. Ma, K.; Du, M.; Liao, M.; Chen, S.; Yin, G.; Liu, Q. Evaluation of wound healing effect of punica granatum L Peel extract on deep second-degree burns in rats. Trop. J. Pharm. Res. 2015, 14, 73-78. [CrossRef]

11. Das, A.K.; Mandal, S.C.; Banerjee, S.K.; Sinha, S.; Saha, B.; Pal, M. Studies on the hypoglycaemic activity of Punica granatum seed in streptozotocin induced diabetic rats. Phytother. Res. 2001, 15, 628-629. [CrossRef]

12. Rosenblat, M.; Hayek, T.; Aviram, M. Anti-oxidative effects of pomegranate juice (PJ) consumption by diabetic patients on serum and on macrophages. Atherosclerosis 2006, 187, 363-371. [CrossRef]

13. Hontecillas, R.; O'Shea, M.; Einerhand, A.; Diguardo, M.; Bassaganya-Riera, J. Activation of PPAR $\gamma$ and $\alpha$ by punicic acid ameliorates glucose tolerance and suppresses obesity-related inflammation. J. Am. Coll. Nutr. 2009, 28, 184-195. [CrossRef]

14. Mirmiran, P.; Fazeli, M.R.; Asghari, G.; Shafiee, A.; Azizi, F. Effect of pomegranate seed oil on hyperlipidaemic subjects: A double-blind placebo-controlled clinical trial. Br. J. Nutr. 2010, 104, 402-406. [CrossRef] [PubMed]

15. Hossin, F.L.A. Effect of pomegranate (Punica granatum) peels and it's extract on obese hypercholesterolemic rats. Pak. J. Nutr. 2009, 8, 1251-1257. [CrossRef]

16. Stowe, C.B. The effects of pomegranate juice consumption on blood pressure and cardiovascular health. Complement. Ther. Clin. Pract. 2011, 17, 113-115. [CrossRef]

17. Wang, Z.; Chen, Y. Antihypertensive Effect of Pomegranate Polyphenols in Spontaneously Hypertensive Rats. China Pharm. 2016, 19, 255-258.

18. Lei, F.; Zhang, X.; Wang, W.; Xing, D.; Xie, W.; Su, H. Evidence of anti-obesity effects of the pomegranate leaf extract in high-fat diet induced obese mice. Int. J. Obes. 2007, 31, 1023. [CrossRef] [PubMed]

19. Betanzos-Cabrera, G.; Guerrero-Solano, J.; Martínez-Pérez, M.; Calderón-Ramos, Z.; Belefant-Miller, H.; Cancino-Diaz, J.C. Pomegranate juice increases levels of paraoxonase1 (PON1) expression and enzymatic activity in streptozotocin-induced diabetic mice fed with a high-fat diet. Food Res. 2011, 44, 1381-1385. [CrossRef]

20. Al-Jarallah, A.; Igdoura, F.; Zhang, Y.; Tenedero, C.B.; White, E.J.; MacDonald, M.E. The effect of pomegranate extract on coronary artery atherosclerosis in SR-BI/APOE double knockout mice. Atherosclerosis 2013, 228, 80-89. [CrossRef]

21. Azadzoi, K.M.; Schulman, R.N.; Aviram, M.; Siroky, M.B. Oxidative stress in arteriogenic erectile dysfunction: Prophylactic role of antioxidants. J. Urol. 2005, 174, 386-393. [CrossRef]

22. Neyrinck, A.M.; Van Hée, V.F.; Bindels, L.B.; De Backer, F.; Cani, P.D.; Delzenne, N.M. Polyphenol-rich extract of pomegranate peel alleviates tissue inflammation and hypercholesterolaemia in high-fat diet-induced obese mice: Potential implication of the gut microbiota. Br. J. Nutr. 2013, 109, 802-809. [CrossRef] 
23. Ismail, T.; Sestili, P.; Akhtar, S. Pomegranate peel and fruit extracts: A review of potential anti-inflammatory and anti-infective effects. J. Ethnopharmacol. 2012, 143, 397-405. [CrossRef]

24. Medjakovic, S.; Jungbauer, A. Pomegranate: A fruit that ameliorates metabolic syndrome. Food Funct. 2013, 4, 19-39. [CrossRef] [PubMed]

25. Hashemi, M.; Kelishadi, R.; Hashemipour, M.; Zakerameli, A.; Khavarian, N.; Ghatrehsamani, S. Acute and long-term effects of grape and pomegranate juice consumption on vascular reactivity in paediatric metabolic syndrome. Cardiol. Young 2010, 20, 73-77. [CrossRef] [PubMed]

26. Wang, J.; Rong, X.; Um, I.S.; Yamahara, J.; Li, Y. 55-week treatment of mice with the unani and ayurvedic medicine pomegranate flower ameliorates ageing-associated insulin resistance and skin abnormalities. Evid.-Based Complement. Altern. Med. 2012, 2012, 350125. [CrossRef]

27. Deng, Y.; Li, Y.; Zheng, T.; Hu, M.; Ye, T.; Xie, Y. The Extract from Punica Granatum (Pomegranate) Leaves Promotes Apoptosis and Impairs Metastasis in Prostate Cancer Cells. J. Sichuan Univ. Med. Sci. Ed. 2018, 48, 8-12. [CrossRef]

28. Khan, N.; Hadi, N.; Afaq, F.; Syed, D.N.; Kweon, M.-H.; Mukhtar, H. Pomegranate fruit extract inhibits prosurvival pathways in human A549 lung carcinoma cells and tumor growth in athymic nude mice. Carcinogenesis 2007, 28, 163-173. [CrossRef] [PubMed]

29. Adams, L.S.; Seeram, N.P.; Aggarwal, B.B.; Takada, Y.; Sand, D.; Heber, D. Pomegranate juice, total pomegranate ellagitannins, and punicalagin suppress inflammatory cell signaling in colon cancer cells. J. Agric. Food Chem. 2006, 54, 980-985. [CrossRef] [PubMed]

30. Karwasra, R.; Kalra, P.; Gupta, Y.K.; Saini, D.; Kumar, A.; Singh, S. Antioxidant and anti-inflammatory potential of pomegranate rind extract to ameliorate cisplatin-induced acute kidney injury. Food Funct. 2016, 7, 3091-3101. [CrossRef]

31. Silva, N.; Fernandes Júnior, A. Biological properties of medicinal plants: A review of their antimicrobial activity. J. Venom. Anim. Toxins Incl. Trop. Dis. 2010, 16, 402-413. [CrossRef]

32. Adiga, S.; Tomar, P.; Rajput, R. Effect of Punica granatum peel aqueous extract on normal and dexamethasone suppressed wound healing in wistar rats. Int. J. Pharm. Sci. Rev. Res. 2010, 5, 34-37.

33. Rajan, S.; Ravi, J.; Suresh, A.; Guru, S. Hidden secrets of Punica granatum use and its effects on oral health: A short review. J. Orofac. Res. 2013, 3, 38-41. [CrossRef]

34. Merskey, H.; Bogduk, N. Classification of Chronic Pain; International Association for the Study of Pain: Seattle, WA, USA, 1994; pp. 3-4.

35. Barrot, M. Tests and models of nociception and pain in rodents. Neuroscience 2012, 211, 39-50. [CrossRef] [PubMed]

36. Millan, M.J. The induction of pain: An integrative review. Prog. Neurobiol. 1999, 57, 1-164. [CrossRef]

37. Woolf, C.J. Pain: Moving from symptom control toward mechanism-specific pharmacologic management. Ann. Intern. Med. 2004, 140, 441-451. [CrossRef] [PubMed]

38. Kaplan, W.; Wirtz, V.J.; Mantel-Teeuwisse, A. Priority Diseases and Reasons for Inclusion (6.23. Low back pain). In Priority Medicines for Europe and the World 2013 Update; WHO: Geneva, Switzerland, 2018.

39. Price, J.R.; Price, M.J.; Hall, A. Pharmacological treatment of pain and pain-related disorders. In APA Handbook of Psychopharmacology; APA handbooks in psychology®series; American Psychological Association: Washington, DC, USA, 2019; pp. 423-449.

40. Borsook, D. A future without chronic pain: Neuroscience and clinical research. Cerebrum 2012, $2012,7$.

41. Jiang, C.; Wang, H.; Wang, Q.; Luo, Y.; Sidlow, R.; Han, X. Prevalence of Chronic Pain and High-Impact Chronic Pain in Cancer Survivors in the United States. JAMA Oncol. 2019, 5, 1224-1226. [CrossRef]

42. Hunskaar, S.; Fasmer, O.B.; Hole, K. Formalin test in mice, a useful technique for evaluating mild analgesics. J. Neurosci. Methods 1985, 14, 69-76. [CrossRef]

43. Le Bars, D.; Gozariu, M.; Cadden, S.W. Animal models of nociception. Pharmacol. Rev. 2001, 53, 597-652.

44. Tjølsen, A.; Lund, A.; Berge, O.-G.; Hole, K. An improved method for tail-flick testing with adjustment for tail-skin temperature. J. Neurosci. Methods 1989, 26, 259-265. [CrossRef]

45. Janssen, P. The inhibitory effect of fentanyl and other morphine-like analgesics on the warm water induced tactile withdrawal reflex in rat. Arzneim. -Forsch. 1963, 13, 502-507.

46. Hamura, H.; Yoshida, M.; Shimizu, K.; Matsukura, T.; Suzuki, H.; Narita, M. Antinociceptive effect of the combination of pentazocine with morphine in the tail-immersion and scald-pain tests in rats. Jpn. J. Pharm. 2000, 83, 286-292. [CrossRef] 
47. Tamaddonfard, E.; Khalilzadeh, E.; Hamzeh-Gooshchi, N.; Seiednejhad-Yamchi, S. Central effect of histamine in a rat model of acute trigeminal pain. Pharmacol. Rep. 2008, 60, 219. [PubMed]

48. Ajaikumar, K.; Asheef, M.; Babu, B.; Padikkala, J. The inhibition of gastric mucosal injury by Punica granatum L. (pomegranate) methanolic extract. J. Ethnopharmacol. 2005, 96, 171-176. [CrossRef] [PubMed]

49. Moghaddam, G.; Sharifzadeh, M.; Hassanzadeh, G.; Khanavi, M.; Hajimahmoodi, M. Anti-ulcerogenic activity of the pomegranate peel (Punica granatum) methanol extract. Food Nutr. Sci. 2013, 4, 43-48. [CrossRef]

50. Labib, R.M.; El-Ahmady, S.H. Antinociceptive, anti-gastric ulcerogenic and anti-inflammatory activities of standardized egyptian pomegranate peel extract. J. Appl. Pharm. Sci. 2015, 5, 48-51. [CrossRef]

51. Gould, I.H.J.; England, J.D.; Liu, Z.; Levinson, S.R. Rapid sodium channel augmentation in response to inflammation induced by complete Freund's adjuvant. Brain Res. J. 1998, 802, 69-74. [CrossRef]

52. Raafat, K.; Samy, W. Amelioration of diabetes and painful diabetic neuropathy by Punica granatum L. Extract and its spray dried biopolymeric dispersions. Evid. -Based Complement. Altern. Med. 2014, 2014, 180495. [CrossRef]

53. Jain, V.; Pareek, A.; Bhardwaj, Y.R.; Singh, N. Attenuating effect of standardized fruit extract of punica granatum $\mathrm{L}$ in rat model of tibial and sural nerve transection induced neuropathic pain. BMC Complement. Altern. Med. 2013, 13, 274. [CrossRef]

54. Dowdall, T.; Meert, T.F. Behavioral evaluation of symptoms of allodynia and hyperalgesia in rats with a tibial and sural nerve transection. J. Neuropath. Pain Symptom Palliation 2005, 1, 29-37. [CrossRef]

55. Wang, R.; Ding, Y.; Liu, R.; Xiang, L.; Du, L. Pomegranate: Constituents, bioactivities and pharmacokinetics. Fruit Veg. Cereal Sci. Biotechnol. 2010, 4, 77-87.

56. BenSaad, L.A.; Kim, K.H. Phytochemical constituents and analgesic activity of ethyl acetate fraction of Punicagranatum L (Punicaceae). Trop. J. Pharm. Res. 2015, 14, 87-93. [CrossRef]

57. Ghorbanzadeh, B.; Mansouri, M.T.; Hemmati, A.A.; Naghizadeh, B.; Mard, S.A.; Rezaie, A. Involvement of $\mathrm{L}$-arginine/NO/cGMP/KATP channel pathway in the peripheral antinociceptive actions of ellagic acid in the rat formalin test. Pharmacol. Biochem. Behav. 2014, 126, 116-121. [CrossRef] [PubMed]

58. Kawabata, A.; Manabe, S.; Manabe, Y.; Takagi, H. Effect of topical administration of l-arginine on formalin-induced nociception in the mouse: A dual role of peripherally formed NO in pain modulation. Br. J. Pharmacol. 1994, 112, 547-550. [CrossRef] [PubMed]

59. Lee, C.J.; Chen, L.G.; Liang, W.L.; Wang, C.C. Anti-inflammatory effects of Punica granatum Linne in vitro and in vivo. Food Chem. 2010, 118, 315-322. [CrossRef]

60. Quachrif, A.; Khalki, H.; Chaib, S.; Mountassir, M.; Aboufatima, R.; Farouk, L. Comparative study of the anti-inflammatory and antinociceptive effects of two varieties of Punica granatum. Pharm. Biol. 2012, 50, 429-438. [CrossRef] [PubMed]

61. Saad, L.B.; Hwi, K.K.; Quah, T. Evaluation of the antinociceptive effect of the ethanolic extract of Punica granatum. Afr. J. Tradit. Complement. Altern. Med. 2014, 11, 228-233. [CrossRef]

62. Zeghad, N.; Madi, A.; Helmi, S.; Belkhiri, A. In vivo analgesic activity and safety assessment of Vitis vinifera L and Punica granatum L fruits extracts. Trop. J. Pharm. Res. 2016, 15, 1915-1921. [CrossRef]

63. Gainok, J.; Daniels, R.; Golembiowski, D.; Kindred, P.; Post, L.; Strickland, R. Investigation of the anti-inflammatory, antinociceptive effect of ellagic acid as measured by digital paw pressure via the Randall-Selitto meter in male Sprague-Dawley rats. AANA J. 2011, 79, S28-S34.

64. Gil, M.I.; Tomás-Barberán, F.A.; Hess-Pierce, B.; Holcroft, D.M.; Kader, A.A. Antioxidant activity of pomegranate juice and its relationship with phenolic composition and processing. J. Agric. Food Chem. 2000, 48, 4581-4589. [CrossRef]

65. Singh, B.; Singh, J.P.; Kaur, A.; Singh, N. Phenolic compounds as beneficial phytochemicals in pomegranate (Punica granatum L.) peel: A review. Food Chem. 2018, 261, 75-86. [CrossRef]

66. Rosillo, M.A.; Sánchez-Hidalgo, M.; Cárdeno, A.; Aparicio-Soto, M.; Sánchez-Fidalgo, S.; Villegas, I. Dietary supplementation of an ellagic acid-enriched pomegranate extract attenuates chronic colonic inflammation in rats. Pharmacol. Res. 2012, 66, 235-242. [CrossRef]

67. Giménez-Bastida, J.A.; González-Sarrías, A.; Larrosa, M.; Tomás-Barberán, F.; Espín, J.C.; García-Conesa, M.T. Ellagitannin metabolites, urolithin A glucuronide and its aglycone urolithin A, ameliorate TNF- $\alpha$-induced inflammation and associated molecular markers in human aortic endothelial cells. Mol. Nutr. Food Res. 2012, 56, 784-796. [CrossRef] [PubMed] 
68. Hollebeeck, S.; Winand, J.; Hérent, M.-F.; During, A.; Leclercq, J.; Larondelle, Y. Anti-inflammatory effects of pomegranate (Punica granatum L.) husk ellagitannins in Caco-2 cells, an in vitro model of human intestine. Food Funct. 2012, 3, 875-885. [CrossRef] [PubMed]

69. Olajide, O.A.; Kumar, A.; Velagapudi, R.; Okorji, U.P.; Fiebich, B.L. Punicalagin inhibits neuroinflammation in LPS-activated rat primary microglia. Mol. Nutr. Food Res. 2014, 58, 1843-1851. [CrossRef] [PubMed]

70. Karwasra, R.; Singh, S.; Sharma, D.; Sharma, S.; Sharma, N.; Khanna, K. Pomegranate supplementation attenuates inflammation, joint dysfunction via inhibition of NF- $\mathrm{KB}$ signaling pathway in experimental models of rheumatoid arthritis. J. Food Biochem. 2019, 43, e12959. [CrossRef]

71. Moreira, J.; Klein-Júnior, L.C.; Cechinel Filho, V.; de Campos Buzzi, F. Anti-hyperalgesic activity of corilagin, a tannin isolated from Phyllanthus niruri L. (Euphorbiaceae). J. Ethnopharmacol. 2013, 146, 318-323. [CrossRef]

72. Bevan, S.; Andersson, D.A. TRP channel antagonists for pain-opportunities beyond TRPV1. Curr. Opin. Investig. Drugs 2009, 10, 655-663.

73. Fernandes, E.; Fernandes, M.; Keeble, J. The functions of TRPA1 and TRPV1: Moving away from sensory nerves. Br. J. Pharmacol. 2012, 166, 510-521. [CrossRef]

74. O'Leary, K.A.; de Pascual-Tereasa, S.; Needs, P.W.; Bao, Y.P.; O’Brien, N.M.; Williamson, G. Effect of flavonoids and vitamin E on cyclooxygenase-2 (COX-2) transcription. Mutat. Res.-Fundam. Mol. Mech. 2004, 551, 245-254. [CrossRef]

75. Takano-Ishikawa, Y.; Goto, M.; Yamaki, K. Structure-activity relations of inhibitory effects of various flavonoids on lipopolysaccharide-induced prostaglandin E2 production in rat peritoneal macrophages: Comparison between subclasses of flavonoids. Phytomedicine 2006, 13, 310-317. [CrossRef]

76. Gao, W.; Zan, Y.; Wang, Z.-J.; Hu, X.-Y.; Huang, F. Quercetin ameliorates paclitaxel-induced neuropathic pain by stabilizing mast cells, and subsequently blocking PKCE-dependent activation of TRPV1. Acta Pharmacol. Sin. 2016, 37, 1166-1177. [CrossRef]

77. Amakura, Y.; Okada, M.; Tsuji, S.; Tonogai, Y. High-performance liquid chromatographic determination with photodiode array detection of ellagic acid in fresh and processed fruits. J. Chromatogr. A 2000, 896, 87-93. [CrossRef]

78. Clifford, M.N.; Scalbert, A. Ellagitannins-nature, occurrence and dietary burden. J. Sci. Food Agric. 2000, 80, 1118-1125. [CrossRef]

79. Mansouri, M.T.; Naghizadeh, B.; Ghorbanzadeh, B. Ellagic acid enhances morphine analgesia and attenuates the development of morphine tolerance and dependence in mice. Eur. J. Pharmacol. 2014, 741, 272-280. [CrossRef] [PubMed]

80. Mansouri, M.T.; Naghizadeh, B.; Ghorbanzadeh, B. Involvement of opioid receptors in the systemic and peripheral antinociceptive actions of ellagic acid in the rat formalin test. Pharmacol. Biochem. Behav. 2014, 120, 43-49. [CrossRef] [PubMed]

81. Mansouri, M.T.; Naghizadeh, B.; Ghorbanzadeh, B. Ellagic acid enhances the antinociceptive action of venlafaxine in mouse acetic acid-induced pain: An isobolographic analysis. Pharmacol. Rep. 2015, 67, 473-477. [CrossRef] [PubMed]

82. Krogh, R.; Yunes, R.; Andricopulo, A. Structure-activity relationships for the analgesic activity of gallic acid derivatives. Farmaco 2000, 55, 730-735. [CrossRef]

83. Miclescu, A.; Gordh, T. Nitric oxide and pain:'Something old, something new'. Acta Anaesthesiol. Scand. 2009, 53, 1107-1120. [CrossRef]

84. Mansouri, M.T.; Naghizadeh, B.; Ghorbanzadeh, B.; Farbood, Y. Central and peripheral antinociceptive effects of ellagic acid in different animal models of pain. Eur. J. Pharmacol. 2013, 707, 46-53. [CrossRef]

85. El-Shitany, N.A.; El-Bastawissy, E.A.; El-desoky, K. Ellagic acid protects against carrageenan-induced acute inflammation through inhibition of nuclear factor kappa B, inducible cyclooxygenase and proinflammatory cytokines and enhancement of interleukin-10 via an antioxidant mechanism. Int. Immunopharmacol. 2014, 19, 290-299. [CrossRef]

86. NCBI. Gallic Acid, CID=370: National Center for Biotechnology Information. 2019. Available online: https://pubchem.ncbi.nlm.nih.gov/compound/Gallic-acid (accessed on 10 December 2019).

87. BenSaad, L.A.; Kim, K.H.; Quah, C.C.; Kim, W.R.; Shahimi, M. Anti-inflammatory potential of ellagic acid, gallic acid and punicalagin A\&B isolated from Punica granatum. BMC Complement. Altern. Med. 2017, $17,47$. [CrossRef] 
88. Santos, A.R.; De Campos, R.O.; Miguel, O.G.; Cechinel-Filho, V.; Yunes, R.A.; Calixto, J.B. The involvement of $\mathrm{K}+$ channels and $\mathrm{Gi} / \mathrm{o}$ protein in the antinociceptive action of the gallic acid ethyl ester. Eur. J. Pharmacol. 1999, 379, 7-17. [CrossRef]

89. Trevisan, G.; Rossato, M.F.; Tonello, R.; Hoffmeister, C.; Klafke, J.Z.; Rosa, F. Gallic acid functions as a TRPA1 antagonist with relevant antinociceptive and antiedematogenic effects in mice. Nauny Schmiedebergs Arch. Pharmacol. 2014, 387, 679-689. [CrossRef] [PubMed]

90. Carvalho Filho, J.M. Pomegranate seed oil (Punica granatum L.): A source of punicic acid (conjugated $\alpha$-linolenic acid). J. Hum. Nutr. Food Sci. 2014, 2, 1-11.

91. Boussetta, T.; Raad, H.; Lettéron, P.; Gougerot-Pocidalo, M.-A.; Marie, J.-C.; Driss, F. Punicic acid a conjugated linolenic acid inhibits TNF $\alpha$-induced neutrophil hyperactivation and protects from experimental colon inflammation in rats. PLoS ONE 2009, 4, e6458. [CrossRef] [PubMed]

92. Patel, C.; Dadhaniya, P.; Hingorani, L.; Soni, M. Safety assessment of pomegranate fruit extract: Acute and subchronic toxicity studies. Food Chem. Toxicol. 2008, 46, 2728-2735. [CrossRef] [PubMed]

93. El Deeb, K.S.; Eid, H.H.; Ali, Z.Y.; Shams, M.M.; Elfiky, A.M. Bioassay-guided fractionation and identification of antidiabetic compounds from the rind of Punica Granatum Var. nana. Nat. Prod. Res. 2019, 1-4. [CrossRef] [PubMed]

94. Gautam, R.K.; Sharma, S.; Sharma, K.; Gupta, G. Evaluation of Antiarthritic Activity of Butanol Fraction of Punica granatum Linn. Rind Extract against Freund's Complete Adjuvant-Induced Arthritis in Rats. J. Environ. Pathol. Toxicol. Oncol. 2018, 37, 53-62. [CrossRef]

95. Vidal, A.; Fallarero, A.; Peña, B.R.; Medina, M.E.; Gra, B.; Rivera, F. Studies on the toxicity of Punica granatum L. (Punicaceae) whole fruit extracts. J. Ethnopharmacol. 2003, 89, 295-300. [CrossRef]

96. Kulkarni, A.P.; Mahal, H.; Kapoor, S.; Aradhya, S. In vitro studies on the binding, antioxidant, and cytotoxic actions of punicalagin. J. Agric. Food. Chem. 2007, 55, 1491-1500. [CrossRef]

97. Cerdá, B.; Cerón, J.J.; Tomás-Barberán, F.A.; Espín, J.C. Repeated oral administration of high doses of the pomegranate ellagitannin punicalagin to rats for 37 days is not toxic. J. Agric. Food. Chem. 2003, 51, 3493-3501. [CrossRef]

98. González-Trujano, M.E.; Pellicer, F.; Mena, P.; Moreno, D.A.; García-Viguera, C. Antinociceptive and anti-inflammatory activities of a pomegranate (Punica granatum L.) extract rich in ellagitannins. Int. J. Food Sci. Nutr. 2015, 66, 395-399. [CrossRef] [PubMed]

99. Bensaad, L.; Hwi, K.K.; Alsereti, M.; Shahimi, M. Evaluation of the analgesic effects of Libyan fresh pomegranate fruit of Punica granatum. PharmaNutrition 2014, 2, 108-109. [CrossRef]

100. Rafraf, M.; Hemmati, S.; Jafarabadi, M.A.; Moghaddam, A.; Haghighian, M.K. Pomegranate (Punica Granatum L.) Peel Hydroalcoholic Extract Supplementation Reduces Pain and Improves Clinical Symptoms of Knee Osteoarthritis: A Randomized Double-Blind Placebo Controlled Study. Iran. Red Crescent Med. J. 2017, 19. [CrossRef]

101. Olapour, S.; Najafzadeh, H. Evaluation Analgesic, Anti-Inflammatory and Antiepileptic Effect of Hydro Alcoholic Peel Extract of "Punica granatum (pomegranate)". Asian J. Med. Sci. 2010, 2, 266-270.

102. Mo, J.; Panichayupakaranant, P.; Kaewnopparat, N.; Nitiruangjaras, A.; Reanmongkol, W. Topical anti-inflammatory and analgesic activities of standardized pomegranate rind extract in comparison with its marker compound ellagic acid in vivo. J. Ethnopharmacol. 2013, 148, 901-908. [CrossRef]

103. Kumar, S.; Maheshwari, K.K.; Singh, V. Central nervous system activity of acute administration of ethanol extract of Punica granatum L. seeds in mice. Indian J. Exp. Biol. 2008, 46, 811-816.

104. Ferreira, L.M.; Sari, M.H.M.; Cervi, V.F.; Gehrcke, M.; Barbieri, A.V.; Zborowski, V.A. Pomegranate seed oil nanoemulsions improve the photostability and in vivo antinociceptive effect of a non-steroidal anti-inflammatory drug. Colloids Surf. B Biointerfaces 2016, 144, 214-221. [CrossRef]

105. Malek, Z.; Dara, S.M.; Jahromy, M.H. Antinociceptive effects of pomegranate (Punica granatum L.) juice and seed extracts on acute corneal pain in mice. World J. Neurosci. 2014, 4, 99-105. [CrossRef]

106. Chakraborthy, G.S. Analgesic activity of various extracts of Punica granatum (Linn) flowers. Int. J. Green Pharm. 2008, 2. [CrossRef] 
107. Sarker, M.; Das, S.C.; Saha, S.K.; Al Mahmud, Z.; Bachar, S.C. Analgesic and anti-inflammatory activities of flower extracts of Punica granatum Linn. (Punicaceae). J. Appl. Pharm. Sci. 2012, 2, 133-136. [CrossRef]

108. Salwe, K.J.; Sachdev, D. Evaluation of Antinociceptive and Anti-inflammatory Effect of the Hydroalcoholic Extracts of Leaves and Fruit Peel of P. Granatum in Experimental animals. Asian J. Pharm. Clin. Res. 2014, 7, 137-141.

(C) 2020 by the authors. Licensee MDPI, Basel, Switzerland. This article is an open access article distributed under the terms and conditions of the Creative Commons Attribution (CC BY) license (http://creativecommons.org/licenses/by/4.0/). 